\title{
Use of a germination bioassay to test compost maturity in Tekelan Village
}

\author{
Wiharyanto Oktiawan ${ }^{1, *}$, Badrus Zaman ${ }^{1}$, and Purwono ${ }^{1}$ \\ ${ }^{1}$ Department of Environmental Engineering, Faculty of Engineering, Diponegoro University, Semarang - Indonesia
}

\begin{abstract}
Livestock waste from cattle farms in Tekelan village, Getasan Subdistrict, Semarang Regency can be grouped into three types, namely solid waste, slurry and waste water. Solid waste (cow dung) was processed into compost, while slurry and waste water were used to make liquid fertilizer. This compost was used as a component of planting media in horticultural crops and potted plants production. We evaluated the toxicity (phytochemical and ecotoxicological) test of compost by using germination index (GI). Vigna radiata seeds are sown on filter paper dampened with compost extract for different times. GI was calculated by relative germination $(\mathrm{G})$ and relative radical length $(\mathrm{L})$. The germination index $(\mathrm{GI})=\mathrm{G} / \mathrm{G} 0 \mathrm{x} \mathrm{L} / \mathrm{L} 0 \mathrm{x}$ 100, where G0 and L0 are values obtained by distilled water as a control. The results showed that germination bioassay and radical length using aquades and groundwater in Tekelan village did not affect the radical length of Vigna radiata. Technically, groundwater in Tekelan village can be used as a germination bioassay control. The cow dung compost substrate appears to have a major influence on compost toxicity. Mature compost was produced on day 14 with a GI of 104.03 .
\end{abstract}

\section{Introduction}

Tekelan Village Community, Getasan Sub-district, Semarang Regency mostly work as vegetable farmers and cattle farm. Livestock waste from cattle farms can be grouped into three types, namely solid waste, slurry and waste water. Communities utilize farm and animal waste to make. This is an appropriate step for treating solid waste. This compost was used as a component of planting media in horticultural crops and potted plants production. These activities are carried out in order to realize organic farming in Tekelan Village.

According to [1], [2] the cultivation of plants in the soil can cause problems due to changes in salinity, soil pathogens, and changes in some of the soil physical and chemical properties that are difficult to solve. This change is due to microbiological activity between compost and biological activity in the compost. Biological processes will continue in a reversible manner until the rob nut nutrients of soil [3].

In order to guarantee the safety of the compost during its use in the agriculture, or as an amendment in degraded soils, certain quality criteria should be filled. These are related to the content of pathogens, heavy metals, organic matter, nutrient content, stability and maturity [4-7]. Good compost quality for plant growth is based on maturity [8] which shows the relationship between compost quality and plant growth. The aerobic biological activity is based on the compost stability of the relationship between compost quality and biological activity in compost [3], [8]. Inadequate and stable compost will inhibit plant growth and negatively impact on soil quality [9]; [10]; [11].

The maturity level of compost can be tested in the laboratory by means of physical, chemical and biological parameter analysis, including microbiological activity [12]. Physical parameters include odor, color, temperature, particle size and inert material. Chemical parameters include carbon and nitrogen analyses $(\mathrm{C} / \mathrm{N}$ ratio in solid and water extract), cation exchange capacity (CEC, total organic-C ratio), water-soluble extract ( $\mathrm{pH}, \mathrm{EC}$, organic-C, ions) Nitrogen minerals $\left(\mathrm{NH}_{4}-\mathrm{N}\right.$ content, $\mathrm{NH}_{4}-\mathrm{N} / \mathrm{NO}_{3}-\mathrm{N}$ ratio), pollutants (heavy metals and organics), Organic matter quality (organic composition: lignin, complex carbohydrates, lipids, sugars), and humification (humification indices and Humic-like substances characterization: elemental and functional group analyses, molecular). Biological parameters include microbial activity indicators, phytotoxicity (germination and plant growth tests), pathogen and ecotoxicity tests [13].

Based on [14] phytotoxicity tests such as germination rate (GR) and RE tests have many advantages. The test is simple, inexpensive and requires only a relatively small sample. Moreover, the seeds can still be used for a long time. Simple and highly reproducible methods, applicable in situ and in vitro, there is no requirement for main equipment, minimal maintenance costs, few required samples (eg water, effluent, soil, sediment), no season, seeds can be easily purchased everywhere, the seeds remain long, and the germination is fast.

In this study, we evaluated the use of bioassay germination as an indicator of compost maturity made by 
Tekelan Village Community, Getasan Subdistrict, Semarang Regency, Indonesia.

\section{Method}

The compost samples used for the germination index test were from tekelan village, Getasan Subdistrict, Semarang regency, Indonesia with coordinates $7^{\circ}$ $25^{\prime} 50.03$ "S and $110^{\circ} 26^{\prime} 17.22 " \mathrm{~T}$. The sample was taken from the composting process pile on days $0,7,14$, and 21. Samples were extracted using aquades with solids ratio: water $1: 10 \mathrm{gr} / 1$. The compost mixture is shaken and played with jartest for 30 minutes. Then the sample is filtered with filter paper. Germination test using petri dish (diameter $10 \mathrm{~cm}$ ) which has been included media planting (tissue paper). Add 10 Vigna radiata to the medium, then add $10 \mathrm{ml}$ of compost extract. Petri dishes were incubated in the dark for 72 hours. The control is carried out in the same way by replacing $10 \mathrm{ml}$ of the compost extract replaced by $10 \mathrm{ml}$ of aquades. After 72 hours incubation, observe the number of seeds affected by negative effects, normal germinated seeds and radicle lengths on tissue paper, both in the addition of compost extract and control.

Relative seed germination and relative radicle length were calculated using equations (1) and (2). The germination index (GI) is calculated using the formula $\mathrm{GI}=(\mathrm{G} / \mathrm{G} 0) \times(\mathrm{L} / \mathrm{L} 0) \times 100$, where $\mathrm{G}$ is the number of normal germinated seeds on the sample substrate, G0 is the number of normal germinated seeds in the control. Where $\mathrm{L}$ is the average of plant roots on the sample substrate and L0 is the average length of plant roots on the control substrate.

\section{Results and Discussion}

\subsection{Water control}

Aquadest and groundwater are used as bioassay germination control substrate. Table 1 shows germination data and radicle length of green beans (Vigna radiata) which are fed to different control substrates. The test is done on green beans Vigna radiata which is equal to 10 unit. The germination of green beans (Vigna radiata) is said to be normal when the seeds show the potential to continue growing into complete plants including roots, hypocotyls, cotyledons, epicotes, and leaves [15]. The results showed that seed germination and radicle length did not show significant differences between aquades and groundwater control substrates. An average number of seeds averaged aquades substrate and ground water substrate respectively as much as 9.70 and 9.80 pieces. While the average teaching length of 2.15 and $2.16 \mathrm{~mm}$.

Based on field studies, real conditions in Tekelan Village, ground water is derived from the spring under the slopes of Mount Merbabu. This indicates that the groundwater can be used instead of aquadest. For practical reasons, the control water selected for mature compost testing is ground water.
Table 1. Germination data and radicle length of green beans Vigna radiata on the control substrate of aquadest and groundwater.

\begin{tabular}{ccc}
\hline substrate & Normal seed (unit) & $\begin{array}{c}\text { radicle length } \\
\text { (mm) }\end{array}$ \\
\hline \multirow{5}{*}{ Aquadest } & 10 & 2,4 \\
& 10 & 2,5 \\
& 10 & 2,0 \\
& 10 & 2,5 \\
Average & 9 & 2,5 \\
& 10 & 2,0 \\
& 10 & 2,0 \\
& 10 & 1,8 \\
& 9 & 1,8 \\
& 9 & 2,0 \\
Groundwater & $\mathbf{9 , 7 0}$ & $\mathbf{2 , 1 5}$ \\
& 10 & 2,5 \\
& 9 & 2,2 \\
& 10 & 2,0 \\
& 10 & 1,9 \\
Average & 10 & 2,5 \\
& 10 & 2,0 \\
& 10 & 2,5 \\
& 9 & 2,0 \\
& 10 & 2,0 \\
& 10 & 2,0 \\
& $\mathbf{9 , 8 0}$ & $\mathbf{2 , 1 6}$ \\
\hline
\end{tabular}

\subsection{Germination seed}

The compost sample was taken from the composting stack of cattle dung on days $0,7,14$, and 21 . This selection was based on the influence of composting time on the quality of the compost identified from the temperature parameters (mesophilic, thermophilic, cooling). In other words, we will know the mesophilic, thermophilic, and cooling effects on the quality of the compost. The germination data and the length of roots of green beans (Vigna radiata) which were incorporated into the different substrate of compost substrate are shown in

Table 2. The test was performed on Vigna radiata which was equal to 10 pieces.

\begin{tabular}{ccc}
\hline $\begin{array}{c}\text { Substrate } \\
\text { on day }\end{array}$ & $\begin{array}{c}\text { Average normal seed } \\
\text { (unit) }\end{array}$ & $\begin{array}{c}\text { Average radicle } \\
\text { length (mm) }\end{array}$ \\
\hline 0 & 3,0 & 2,0 \\
7 & 6,5 & 2,3 \\
14 & 8,0 & 2,8 \\
21 & 9,5 & 3,5 \\
\hline
\end{tabular}

The results showed that the average number of green beans (Vigna radiata) most commonly produced from 21 days compost substrate as much as 9.5 pieces. On day 0 , 7 th, and 14th has a value below 9.5 pieces. This difference indicates the presence of germination inhibitors on each substrate. Phytotoxic compounds such as phenol, ethylene and ammonia compounds, excessive 
salt accumulation, and organic acids can inhibit seed germination [16]. The same thing happens to the roots of the roots of green beans. The average radicle length of $3.5 \mathrm{~mm}$ produced from the compost substrate on the $21 \mathrm{st}$ day. At the end of the test of germination, the seeds that do not sprout are said to be dead, dead seeds and hardened seedlings [15].

\subsection{Germination Index (GI)}

The response of green bean plants Vigna radiata to the toxicity of the compost extract during the cow dung composting period in relative seed germination and the relative root extension percentage is shown in Table 3.

Table 3. Germination Index (GI) value of cow dung compost extract at composting time of $0,7,14$, and 21 days

\begin{tabular}{cc}
\hline Substrate on day & GI \\
\hline 0 & 29,13 \\
7 & 58,31 \\
14 & 104,03 \\
21 & 173,35 \\
\hline
\end{tabular}

At the beginning of composting, green bean GI values Vigna radiata were very low with an initial value of 29.13 compared with groundwater controls, probably due to the phytotoxic effects of ammonia and low molecular weight organic acids [16], but when composting took place, GI increases. According to [16], compost is considered mature if the GI value is higher than $60 \%$, compared with control. By the time the composting lasted for 14 days, the value increased to 104.03 and on the 21 st day to 173.35 . This suggests that the phytotoxicity of the compost pile has been lost. Loss of phytotoxicity is a measure of the maturity level of compost $[16,17]$.

Based on GI value, cow dung compost in Tekelan village matured on the 14 th day.

\section{Conclusion}

This study showed that germination test and root elongation test using aquades and groundwater in tekelan village did not affect the length of roots of green beans (Vigna radiata). Technically, groundwater in tekelan village can be used as a germination test control. The cow dung compost substrate appears to have a major influence on compost toxicity. Mature compost was produced on day 14 with a GI of 104.03 . Further research will be more interesting by ensuring the tekelan villagers can apply this test to other plant fertilizers.

\section{The acknowledgments}

Thank you to DRPM DIKTI for funding this research through IbM grant with contract number 007/SP2H /PPM/DRPM/V/2017 financing year 2017.

\section{References}

1. N. F. Gariglio, A. Pilatti, D. E. Gonzalezrossia, M.R. Acosta, New Zealand Journal of Crop and Horticultural Science, Vol. 30: 135-139, (2002).

2. E. Martinez Caldevilla, Garcia Lozano, M. Cultivos sin suelo. Hortalizas en clima mediterraneo. Compendia de Horticultura 3, 123 p, (1993).

3. S. Mangkoedihardjo, J. Appl. Sci. Environ. Mgt. September, Vol. 10 (3) 83 - 85, (2006)

4. M. Soumaré, F.M.G. Tack, M.G. Verloo, Waste Manage. 23 (6), 517-522, (2003)

5. C. Tognetti, M.J. Mazzarino, F. Laos, Bioresour. Technol. 98 (5), 1067-1076, (2007)

6. M.T. Barral, A. Moldes, Y. Cendón, F. DiazFierros, Waste Manage. Res. 25 (2), 99-108, (2007)

7. P. Wang, C. M.Changa, M. E. Watson, W. A. Dick, Y. Chen, H. A. J. Hoitink Soil Biol Biochem 36: 767-776, (2004).

8. R. H. Llewelyn, Development of standard laboratory based test to measure compost stability. The Waste \& Resources Action Programme The Old Academy, 21 Horse Fair, Banbury, Oxon OX16 0AH, (2005).

9. R. Riffaldi, R. Levi-Minzi, A. Pera, M. De Bertoldi, Waste Manage. Res. 4 (4), 387-396, (1986)

10. L. Wu, L.Q. Ma, G.A. Martinez, J. Environ. Qual. 29 (2), 424-429, (2000)

11. J.C. Tang, Y. Inoue, T. Yasuta, S. Yoshida, A. Katayama, Soil Sci. Plant Nutr. 49 (2),273-280, (2003)

12. A. Cesaro, V. Belgiorno, M. Guida, Resour. Conserv. Recycl. 94, 72-79, (2015)

13. M.P. Bernal, J.A. Alburquerque, R. Moral, A review. Bioresource Technology 100, 5444-5453, (2009)

14. A. Priac, B. Pierre-Marie, G.C. Gre, C. R. Biologies 340, 188-194, (2017)

15. International Seed Testing Association, International rules for seed testing, Seed Sci. Technol., 27: 333, (1999)

16. S. M. Selim, M. S. Zayed, H. M. Atta, Nature and Science 10(2), (2012)

17. F. Zucconi, and M. de Bertoldi, Elsevier Applied Science. pp, 30-50, (1987). 